\title{
SIDIK LINTAS KARAKTER PERTUMBUHAN DAN KOMPONEN HASIL DENGAN HASIL PADA 15 GENOTIPE HIBRIDA JAGUNG
}

\author{
Hellianti Pennita $^{1}$, Catur Herison ${ }^{2}$, Marwanto $^{2}$, Rustikawati ${ }^{2 *}$ \\ ${ }^{1}$ Program Studi Magister Agroekoteknologi, Fakultas Pertanian Universitas Bengkulu \\ ${ }^{2}$ Program Studi Agroekoteknologi, Fakultas Pertanian Universitas Bengkulu \\ * Corresponding Author: rustikawati@unib.ac.id
}

\begin{abstract}
[PATH ANALYSIS OF GROWTH CHARACTERS AND YIELD COMPONENTS WITH THE YIELD OF 15 GENOTYPES OF MAIZE HYBRID]. Determination of traits used as the selection criteria are based on the trait(s) that have a close relationship to the yield. The aims of this research were to measure the closeness of the relationship between morphological (growth and yield component) traits and crop yield, and to determine the trait that directly or indirectly affected on maize yield. The research was conducted in Rimbo Kedui's Village, South Seluma Subdistrict, Seluma District, Bengkulu Province on May 2017 to August 2017. The experimental design used was a Complete Randomized Block Design (CRBD) in a single factor with 3 replications. The treatments were 15 maize hybrid genotypes, consisting of CT1, CT2, CT3, CT4, CT5, CT6, CT7, CT8, CT9, CT10, CT11, CT12, CT13, CT14, and CT15. The data were statistically analyzed by analysis of varians (ANOVA) with $\mathrm{P}_{(\mathrm{a}=5 \%)}$. The qualitative data were analyzed descriptively. The result of correlation analysis revealed that the yield of maize hybrids highly correlated to some growth and yield component factors. High-yielding maize hybrids were supported by higher ear diameter, plant fresh weight, plant dry weight, plant height, the number of seeds per ear. Plant dry weight became the variable that has the highest direct effect with positive correlation on the yield. The second highest rank was the number of seeds per ear with also a positive correlation value. Yield improvement of maize hybrid, therefore, can be obtained by fostering the plant total biomass and/or by multiplying the number of seeds per ear.
\end{abstract}

Keyword: selection criteria, genotype, correlation analysis, path analysis

\begin{abstract}
ABSTRAK
Penentuan sifat-sifat yang digunakan sebagai kriteria seleksi didasarkan atas sifat-sifat yang memiliki hubungan erat dengan hasil tanaman. Penelitian ini bertujuan untuk mengukur tingkat kedekatan hubungan antara sifat morfologi (pertumbuhan dan komponen hasil) dan hasil tanaman, dan menentukan sifat yang berpengaruh langsung maupun tidak langsung terhadap hasil pada tanaman jagung. Penelitian dilakukan di Desa Rimbo Kedui Kecamatan Seluma Selatan Kabupaten Seluma, Provinsi Bengkulu pada bulan Mei 2017 hingga Agustus 2017. Rancangan percobaan yang digunakan adalah Rancangan Acak Kelompok Lengkap (RAKL) faktor tunggal dengan 3 ulangan dan sebagai perlakuannya adalah 15 genotipe jagung hibrida, terdiri atas CT1, CT2, CT3, CT4, CT5, CT6, CT7, CT8, CT9, CT10, CT11, CT12, CT13, CT14, CT15. Data hasil pengamatan dianalisis secara statistik dengan analisis varians pada taraf $\mathrm{a}=5 \%$. Data kualitatif dianalisis secara deskriptif. Hasil analisis korelasi menunjukkan hasil hibrida jagung berkaitan erat dengan faktor pertumbuhannya. Hibrida jagung yang berproduksi tinggi didukung oleh tingginya diameter tongkol, bobot brangkasan segar, bobot brangkasan kering, tinggi tanaman, dan jumlah biji/tongkol. Bobot berangkasan kering menjadi variabel yang berpengaruh langsung dengan nilai korelasi positif tertinggi terhadap hasil. Peringkat kedua tertinggi adalah jumlah biji/tongkol dengan nilai yang juga positif. Peningkatan hasil jagung hibrida dapat diperoleh melalui peningkatan total biomasa tanaman dana tau peningkatan jumlah biji/tongkol.
\end{abstract}

Kata kunci: kriteria seleksi, jagung, analisis korelasi, sidik lintas 


\section{PENDAHULUAN}

Jagung (Zea mays L.) merupakan tanaman golongan serealia yang memiliki kedudukan penting di sektor ekonomi dunia. Di Indonesia, tanaman jagung merupakan bahan pangan kedua setelah padi karena memiliki kandungan karbohidrat, protein, dan kalori yang hampir sama dengan beras. Beberapa wilayah di Indonesia, dan juga negara lain menggunakan jagung sebagai bahan pangan pokok (Riwandi et al., 2014).

Permintaan akan jagung secara nasional yang terus meningkat setiap tahunnya sehingga harus produksi jagung dalam negeri perlu ditingkatkan untuk memenuhi kebutuhan tersebut. Produksi jagung tahun 2018 sebanyak 30,1 juta ton. Produksi tersebut meningkat rata-rata $12,49 \%$ per tahun, dengan pertambahan luas areal panen $11 \%$ dan peningkatan produktivitas $1,42 \%$. Sedangkan volume impor jagung pada tahun 2018 sebesar 477 ribu ton (Badan Pusat Statistik, 2018).

Upaya peningkatan produksi jagung dapat di lakukan melalui intensifikasi budidaya dan pemanfaatan varietas-varietas berdaya hasil tinggi. Perakitan varietas jagung unggul yang berkualitas serta adaptif dengan lingkungan melalui berbagai program pemuliaan merupakan faktor penentu keberhasilan peningkatan produktivitas tanaman. Pada umumnya jagung hibrida memberikan hasil lebih tinggi dari pada jagung varietas bersari bebas (Taufik et al., 2010).

Keberhasilan pemuliaan jagung hibrida memerlukan pengetahuan tentang hubungan antar sifat, terutama dengan hasil. Korelasi merupakan teknik statistik yang digunakan untuk menguji derajat keeratan hubungan antar dua variabel atau lebih. Penentuan sifat-sifat yang digunakan sebagai kriteria seleksi didasarkan atas sifat-sifat yang memiliki hubungan erat dengan hasil tanaman. Sifat-sifat yang berkorelasi tinggi dan positif serta mendukung peningkatan hasil perlu mendapat prioritas di dalam menetapkan kriteria seleksi. Sebaliknya sifat-sifat berkorelasi tinggi dan positif namun tidak mendukung peningkatan hasil tidak perlu diprioritaskan dalam penetapan kriteria seleksi. Pada tanaman jagung, hasil berkorelasi positif dengan bobot 100 biji, diameter tongkol, jumlah biji/tongkol, panjang tongkol, tinggi tanaman dan tinggi tongkol (Reddy \& Jabeen, 2016). Karakter yang menonjol antar spesies jagung adalah karakter pada tongkol jagung (Mustofa et al., 2013).

Analisis lintas merupakan pengembangan metode analisis korelasi. Analisis lintas dapat menjelaskan keeratan hubungan antar sifat dengan cara menguraikan koefisien korelasi menjadi pengaruh langsung dan pengaruh tidak langsung. Metode ini memecah koefisien korelasi antara masing-masing karakter yang dikorelasikan dengan hasil menjadi dua komponen, yaitu pengaruh langsung dan pengaruh tidak langsung, sehingga hubungan kausal di antara karakter yang dikorelasikan dapat diketahui. Sidik lintas dapat digunakan untuk mengetahui adanya komponen pertumbuhan, komponen hasil yang mempunyai pengaruh langsung dan tidak langsung terhadap bobot buah, dengan demikian seleksi karakter yang berkaitan dengan bobot buah menjadi lebih efektif. Haydar et al.,(2007) dalam penelitiannya menguraikan bahwa tinggi tanaman pada saat berbunga dan jumlah bunga merupakan karakter yang paling penting kontribusinya terhadap hasil tomat.

Hasil peneltian Priyanto et al. (2016) menunjukkan bahwa karakter komponen hasil yang berkorelasi dengan hasil biji adalah jumlah tongkol panen, bobot kupasan segar, panjang tongkol, diameter tongkol, jumlah biji/baris, rendemen, dan bobot 100 biji. Pada tanaman kedelai karakter bobot polong isi/tanaman berpengaruh langsung paling besar terhadap bobot biji kering/tanaman.

Penelitian ini bertujuan untuk mengukur tingkat keeratan hubungan antara sifat morfologi dan hasil tanaman, serta menentukan sifat yang berpengaruh langsung maupun tidak langsung terhadap hasil pada tanaman jagung.

\section{METODE PENELITIAN}

Penelitian dilaksanakan pada bulan Mei 2017 Agustus 2017 di Desa Rimbo Kedui Kecamatan Seluma Selatan Kabupaten Seluma, Provinsi Bengkulu. Lokasi penelitian terletak pada. ketinggian tempat \pm 50 mdpl.dengan jenis tanah Ultisol.

Penelitian ini menggunakan Rancangan Acak Kelompok Lengkap (RAKL) faktor tunggal dengan 3 ulangan. Sebagai perlakuan adalah 15 genotipe hibrida jagung, terdiri atas CT1, CT2, CT3, CT4, CT5, CT6, СT7, СТ8, СТ9, СТ10, СТ11, СТ12, СТ13, СТ14, CT15. Sebagai unit percobaan adalah petakan percobaan yang berukuran $2,5 \mathrm{~m} \mathrm{x} 3 \mathrm{~m}$.

Pupuk dasar yang diberikan adalah urea $200 \mathrm{~kg} /$ ha, $\mathrm{KCl} 100 \mathrm{~kg} / \mathrm{ha}$ dan TSP $200 \mathrm{~kg} /$ ha yang ditugal dengan jarak $10 \mathrm{~cm}$ dari lubang tanam. Penyiraman dilakukan sekali sehari, yaitu pagi atau sore hari. Pengendalian gulma dilakukan dengan cara mencabut gulma yang tumbuh di dalam petakan. Pembumbunan dilakukan bersamaan dengan pengendalian gulma dengan cara menaikkan tanah di sekitar tanaman. Panen dilakukan setelah tongkol menunjukkan ciri-ciri rambut jagung telah mengering dan biji jagung telah penuh, dan apabila ditekan tidak menunjukkan bekas tekanan atau tidak pecah.

Pengamatan dilakukan terhadap lima tanaman sampel yang ditetapkan secara acak. Variabel pengamatan terdiri atas variabel pertumbuhan vegetatif tanaman dan generatif tanaman. Variabel pertumbuhan vegetatif yang diamati terdiri atas tinggi tanaman, diameter batang, lebar daun, jumlah daun, bobot segar brangkasan, bobot kering brangkasan dan volume akar. Adapun variabel generatif tanaman yang diamati meliputi umur panen diameter tongkol, panjang tongkol, jumlah 
baris biji/tongkol, jumlah biji/tongkol, bobot 100 biji, dan bobot biji kering/petak.

Data hasil pengamatan dianalisis secara statistik dengan analisis varians pada taraf 5\%. Data kualitatif dianalisis secara deskriptif. Analisis korelasi dan sidik lintas dilakukan untuk mempelajari hubungan antara komponen pertumbuhan, komponen hasil dan hasil. Koefisien korelasi diduga dengan rumus:

$$
r^{2}=\frac{\operatorname{cov} x y}{\sqrt{\sigma^{2}} x \cdot \sigma^{2} y}
$$

Keterangan : COVxy : Kovarian genotipik antar karakter $\mathrm{x}$ dan $\mathrm{y} ; \mathrm{r}^{2}$ : Koefisien determinasi ; $\sigma 2 \mathrm{x}$ : Ragam karakter $\mathrm{x} ; \sigma 2 \mathrm{y}$ : Ragam karakter $\mathrm{y}$

Sidik lintas berdasarkan persamaan simultan digunakan dengan rumus sebagai berikut (Singh \& Chaudary 1979)

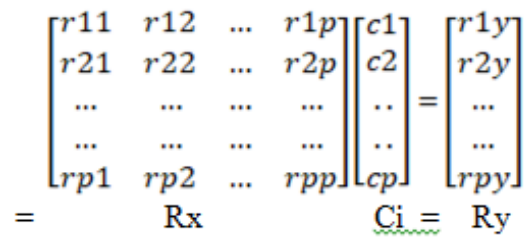

Keterangan :

$\mathrm{Rx}$ : Matriks korelasi antar peubah bebas; $\mathrm{Rx}^{-1}=$ invers matriks $\mathrm{Rx}$.

$\mathrm{Ci}$ : Vektor koefisien lintasan yang menunjukkan pengaruh langsung setiap peubah bebas yang telah dibakukan terhadap peubah tak bebas.

Ry: Vektor koefisien korelasi antara peubah bebas $\mathrm{Xi}(\mathrm{i}=1,2, \ldots . . \mathrm{p})$

Berdasarkan persamaan di atas, nilai $\mathrm{Ci}$ (pengaruh langsung) dapat dihitung menggunakan rumus (Gasperz 1995).

\section{HASIL DAN PEMBAHASAN}

Lahan yang digunakan dalam penelitian ini berada pada ketinggian $\pm 50 \mathrm{~m}$ di atas permukaan laut, memiliki curah hujan sedang dengan curah hujan rata-rata selama penelitian sebesar $249,2 \mathrm{~mm} /$ bulan. Curah hujan pada saat penanaman sebesar 214,15 mm/bulan (bulan Mei 2017), saat tanaman masuk fase pembungaan berkisar $117,5 \mathrm{~mm} /$ bulan dan 194,0 mm/bulan (bulan Juli 2017 dan Agustus 2017) dan saat tanaman masuk fase pembentukan biji hingga panen yaitu 194,0 $\mathrm{mm} /$ bulan (bulan Agustus 2017). Menurut Balai Besar Pengkajian dan Pengembangan Teknologi Pertanian (2009), curah hujan yang ideal untuk budidaya tanaman jagung yaitu berkisar 100-140 mm/bulan. Dengan demikian penelitian ini mendapat curah hujan yang lebih tinggi yang berdampak terhadap serangan penyakit yang relatif tinggi.
Selama penelitian berlangsung terdapat serangan hama belalang dan ulat tanah (Agrotis sp) baik pada fase vegetatif maupun generatif. Serangan hama tidak mempengaruhi pertumbuhan tanaman dapat dikendalikan menggunakan pestisida berbahan aktif Profenofos $E C$ dengan konsentrasi $2 \mathrm{~mL} / \mathrm{L}$ air dengan dosis $1 \mathrm{~L} / \mathrm{ha}$. Sedangkan penyakit yang menyerang tanaman yaitu busuk tongkol yang terjadi pada fase generatif akhir tanaman. Tanaman terserang penyakit busuk tongkol dapat dikendalikan dengan menggunakan pestisida berbahan aktif Mankozeb secara intensif dengan konsentasi $3 \mathrm{~g} / \mathrm{L}$ air dengan volume semprot $500 \mathrm{~L} / \mathrm{ha}$.

Jenis tanah di lokasi penelitian adalah Ultisol dengan pH 4.6, kandungan C-organik 4.99\%, Al-dd 1,06 (me/100),K-dd 0,49(me/100g) dan kadar air 9,01\%. Hasil analisis tanah tersebut sudah memenuhi kriteria syarat tumbuh tanaman jagung. Akan tetapi, untuk $\mathrm{pH}$ tanah harus dilakukan peningkatan karena $\mathrm{pH}$ yang baik untuk tanaman jagung berkisar antara 5,6 - 7,5 (Balai Besar Pengkajian dan Pengembangan Teknologi Pertanian, 2009).

Pada tanaman jagung, hasil merupakan karakter yang kompleks dan tergantung pada berbagai karakter yang berkontribusi. Oleh karena itu, asosiasi karakter penting dipelajari untuk menilai hubungan antara hasil dan komponen hasil yang dapat dimanfaatkan untuk meningkatkan kegunaan seleksi. Dari empat belas sifat yang diamati, empat di antaranya lebar daun, diameter tongkol, jumlah baris biji dan bobot biji/ petak menunjukkan keragaman nyata antar genotip sedangkan sebelas sifat lainnya tidak menunjukkan keragaman antar genotipe (Tabel 1).

Data dari variabel yang diamati memiliki koefisien keragaman berkisar 0,95-35,43\%. Nilai terendah terdapat pada variabel pengamatan umur panen $(\mathrm{KK}=0,95 \%)$ sedangkan nilai koefisien keragaman paling tinggi pada pengamatan variabel bobot 100 biji $(\mathrm{KK}=35,43 \%)$. Koefisien keragaman genotipe yang tertinggi adalah lebar daun diikuti oleh bobot biji/petak, diameter tongkol, jumlah baris biji, bobot brangkasan kering, bobot brangkasan segar, umur panen, bobot 100 biji, volume akar, panjang tongkol, tinggi tanaman, jumlah daun, jumlah biji/tongkol dan diameter batang (Tabel 1).

Keempat sifat tersebut merupakan produk akhir dari proses pertumbuhan tanaman yang secara fisiologis sangat tergantung pada faktor genetik dan kondisi lingkungan, baik lingkungan makro maupun mikro. Karena itu, individu-individu yang secara genetika berbeda akan menghasilkan penampilan tanaman berbeda. Demikian juga jika individu-individu dalam populasi memberi respon yang berbeda maka penampilan akhir juga akan sangat berbeda.

Koefisien korelasi memperlihatkan hubungan yang erat antar dua variabel. Nilai koefisien korelasi berkisar antara -1 hingga +1 . Jika diperoleh nilai korelasi nol, bermakna dapat disimpulkan bahwa tidak terdapat 
korelasi antara kedua sifat tersebut. Jika didapat nilai koefisien semakin mendekati +1 hubungan yang ditunjukkan sangat erat. Jika nilai korelasi semakin mendekati +1 berarti peningkatan suatu sifat akan diikuti oleh peningkatan sifat yang lainnya dan semakin mendekati 1 berarti peningkatan suatu sifat akan mengurangi sifat yang lainnya. Sedangkan kriteria derajat keeratan berdasarkan koefisien korelasinya yaitu 0 : tidak ada korelasi antara dua variabel, $0-0,25$ : korelasi sangat rendah, $0,25-0,5$ : korelasi sedang, $0,5-0,75$ : korelasi tinggi, $0,75-0,99$ : korelasi sangat tinggi, sedangkan 1: korelasi sempurna (Sarwono, 2009).

Tabel 1. Nilai F hitung peubah pertumbuhan dan hasil jagung 15 genotipe hibrida jagung

\begin{tabular}{|c|c|c|c|c|c|}
\hline \multirow{3}{*}{$\begin{array}{c}\text { Variabel } \\
\text { ggi tanaman }\end{array}$} & \multicolumn{4}{|c|}{ Nilai F hitung } & \multirow{3}{*}{$\begin{array}{r}\text { KK \% } \\
12.33\end{array}$} \\
\hline & \multirow{2}{*}{$\frac{\text { Blok }}{0.49}$} & \multicolumn{3}{|c|}{ Genotipe } & \\
\hline & & Ns & 1.15 & Ns & \\
\hline Diameter batang & 0.02 & Ns & 0.36 & Ns & 4.92 \\
\hline Jumlah daun & 0.71 & Ns & 0.96 & Ns & 2.86 \\
\hline $\begin{array}{l}\text { Bobot } \\
\text { brangkasan segar }\end{array}$ & 1.25 & Ns & 1.73 & Ns & 26.51 \\
\hline $\begin{array}{l}\text { Bobot } \\
\text { brangkasan } \\
\text { kering }\end{array}$ & 1.30 & Ns & 1.86 & Ns & 25.88 \\
\hline Volume Akar & 0.01 & Ns & 1.33 & Ns & 31.95 \\
\hline Lebar Daun & 2.25 & $\mathrm{Ns}$ & 7.79 & $*$ & 2.08 \\
\hline Umur panen & 4.3 & $*$ & 1.46 & Ns & 0.95 \\
\hline Diameter tongkol & 1.25 & Ns & 4.02 & $*$ & 5.27 \\
\hline Panjang tongkol & 0.84 & Ns & 1.33 & Ns & 8.14 \\
\hline Jumlah baris biji & 0.45 & Ns & 2.62 & * & 14.64 \\
\hline $\begin{array}{l}\text { Jumlah biji/ } \\
\text { tongkol }\end{array}$ & 0.69 & Ns & 0.64 & Ns & 19.87 \\
\hline Bobot biji/petak & 4.96 & $*$ & 4.2 & $*$ & 11.01 \\
\hline Bobot 100 biji & 2.17 & Ns & 1.45 & Ns & 35.43 \\
\hline
\end{tabular}

Keterangan : * berpengaruh nyata pada taraf 5\% ns berpengaruh tidak nyata pada taraf $5 \%$

Secara umum komponen pertumbuhan terhadap bobot berangkasan segar dan bobot berangkasan kering memiliki hubungan dengan derajat keeratan antara sangat rendah sampai sempurna $(-0.01<\mathrm{r}<1)$ (Tabel 2). Korelasi sempurna ditunjukkan oleh bobot berangkasan segar dengan bobot berangkasan kering $(\mathrm{r}=1)$ diikuti tinggi tanaman dengan bobot berangkasan kering $(\mathrm{r}=0,72)$, tinggi tanaman dengan bobot berangkasan segar $(\mathrm{r}=0,71)$. Tinggi tanaman memberikan pengaruh terhadap pertumbuhan, diduga disebabkan oleh intensitas cahaya yang diperoleh tanaman akan semakin banyak bila tanaman semakin tinggi. Tanaman yang lebih tinggi membutuhkan lebih banyak nutrisi tanaman untuk melengkapi pertumbuhan vegetatif. Tanaman semakin tinggi menunjukkan umur tanaman semakin lama, sehingga bobot tanaman yang dihasilkan semakin besar. Berdasarkan nilai korelasi komponen pertumbuhan yang tinggi dan positif maka seleksi suatu sifat dapat dilakukan terhadap sifat yang lainnya.

Komponen pertumbuhan secara umum berkorelasi positif sedang hingga sangat tinggi terhadap komponen hasil $(0.5<\mathrm{r}<0.99)$. Hal ini menjelaskan bahwa peningkatan komponen sifat pertumbuhan maka akan meningkatkan komponen hasil dari tanaman jagung. Tanaman yang memiliki komponen pertumbuhan yang baik seperti tinggi tanaman, bobot berangkasan segar, dan bobot berangkasan kering, maka akan lebih baik dalam peningkatan hasil. Tanaman yang pertumbuhannya baik akan tumbuh tinggi dan besar, sehingga dapat menyimpan cadangan makanan selain akar sehingga dapat membantu peningkatan produksi tanaman (Rahni., 2012). Diameter tongkol memiliki korelasi yang sedang sampai sangat tinggi dan positif dengan tinggi tanaman $(\mathrm{r}=0,54)$, bobot berangkasan segar $(r=0,77)$, bobot berangkasan kering $(r=0,75)$. Berdasarkan nilai korelasi yang sedang sampai sangat tinggi, maka seleksi dapat dilakukan melalui sifat tinggi tanaman, bobot berangkasan segar dan bobot berangkasan kering.

Komponen hasil (diameter tongkol, panjang tongkol, jumlah baris biji, jumlah biji/tongkol, dan bobot 100 biji) umumnya menunjukkan korelasi yang sangat rendah sampai tinggi $(-0.01<\mathrm{r}<$ 0.75 ). Korelasi tinggi ditunjukkan pada diameter tongkol dengan jumlah biji/tongkol $(\mathrm{r}=0,68)$ dan panjang tongkol dengan bobot 100 biji $(\mathrm{r}=0,66)$. Hal ini disebabkan karena besar dan panjang tongkol berpengaruh terhadap komponen hasil semakin besar dan panjangnya tongkol maka biji yang didapat pun akan semakin banyak. Hasil penelitian yang diperoleh Surtinah (2018) menunjukkan bahwa sifat panjang tongkol berkelobot berkorelasi positif terhadap bobot tongkol berkelobot dan tanpa klobot.

Komponen pertumbuhan (pertumbuhan, yaitu tinggi tanaman, diameter batang, jumlah daun, lebar daun, bobot berangkasan segar, bobot berangkasan kering, volume akar dan umur panen) terhadap hasil memiliki hubungan dengan derajat keeratan antara sangat rendah sampai sangat tinggi $(-0.01<\mathrm{r}<$ 0.99). Korelasi sangat tinggi ditunjukkan oleh bobot berangkasan kering $(\mathrm{r}=0,77)$ diikuti oleh bobot berangkasan segar $(r=0,76)$ dan tinggi tanaman $(r=0,65)$. Bobot tanaman berpengaruh nyata terhadap hasil (Surtinah, 2018). Peningkatan tinggi tanaman dapat menyerap sinar matahari dan hasil fotosintesis, sehingga semakin meningkatkan hasil biji dan ditranslokasikan untuk pembentukan biji pada fase generatif (Herawati et al., 2018). 
Tabel 2. Korelasi antar sifat tanaman jagung

\begin{tabular}{|c|c|c|c|c|c|c|c|c|c|c|c|c|c|c|}
\hline & TT & DB & JD & LD & BBB & BBK & VA & UP & DT & $\mathrm{PT}$ & JBB & JBIT & B100 & BBPP \\
\hline$\overline{\mathrm{TT}}$ & 1 & $-0,49 \mathrm{~ns}$ & $0,31 \mathrm{~ns}$ & $0,43 \mathrm{~ns}$ & $0,71 * *$ & $0,72 * *$ & $0,37 \mathrm{~ns}$ & $-0,16 \mathrm{~ns}$ & $0,54^{*}$ & $0,18 \mathrm{~ns}$ & $-0,17 \mathrm{~ns}$ & $0,29 \mathrm{~ns}$ & $0,13 \mathrm{~ns}$ & $0,65 * *$ \\
\hline DB & & 1 & $-0,19 \mathrm{~ns}$ & $-0,70 \mathrm{~ns}$ & $-0,38 \mathrm{~ns}$ & $-0,39 \mathrm{~ns}$ & $-0,15 \mathrm{~ns}$ & $0,31 \mathrm{~ns}$ & $-0,34 n s$ & $-0,31 \mathrm{~ns}$ & $-0,30 \mathrm{~ns}$ & $-0,37 n s$ & $-0,15 n s$ & $-0,38 n s$ \\
\hline JD & & & 1 & $0,26 \mathrm{~ns}$ & $0,20 \mathrm{~ns}$ & $0,19 \mathrm{~ns}$ & $-0,24 \mathrm{~ns}$ & $-0,40 \mathrm{~ns}$ & $-0,02 \mathrm{~ns}$ & $0,20 \mathrm{~ns}$ & $-0,57 \mathrm{~ns}$ & $-0,09 \mathrm{~ns}$ & $0,03 \mathrm{~ns}$ & $-0,03 n s$ \\
\hline LD & & & & 1 & $0,28 \mathrm{~ns}$ & $0,04 \mathrm{~ns}$ & $0,15 \mathrm{~ns}$ & $-0,08 \mathrm{~ns}$ & $0,24 \mathrm{~ns}$ & $0,07 \mathrm{~ns}$ & $0,32 \mathrm{~ns}$ & $0,25 \mathrm{~ns}$ & $0,36 \mathrm{~ns}$ & $0,14 \mathrm{~ns}$ \\
\hline BBB & & & & & 1 & $1,00 * * *$ & $0,24 \mathrm{~ns}$ & $-0,49 \mathrm{~ns}$ & $0,77^{* *}$ & $0,49 \mathrm{~ns}$ & $-0,14 n s$ & $0,44 \mathrm{~ns}$ & $0,31 \mathrm{~ns}$ & $0,76^{* *}$ \\
\hline BBK & & & & & & 1 & $0,26 \mathrm{~ns}$ & $-0,45 \mathrm{~ns}$ & $0,75^{* *}$ & $0,46 \mathrm{~ns}$ & $-0,14 n s$ & $0,43 \mathrm{~ns}$ & $0,33 \mathrm{~ns}$ & $0,77 * *$ \\
\hline VA & & & & & & & 1 & $0,22 \mathrm{~ns}$ & $0,24 \mathrm{~ns}$ & $0,00 \mathrm{~ns}$ & $0,16 \mathrm{~ns}$ & $-0,14 n s$ & $0,47 \mathrm{~ns}$ & $0,36 \mathrm{~ns}$ \\
\hline UP & & & & & & & & 1 & $-0,41 \mathrm{~ns}$ & $-0,51 \mathrm{~ns}$ & $0,14 \mathrm{~ns}$ & $-0,39 n s$ & $0,10 \mathrm{~ns}$ & $-0,19 \mathrm{~ns}$ \\
\hline DT & & & & & & & & & 1 & $0,35 \mathrm{~ns}$ & $0,26 \mathrm{~ns}$ & $0,68 * *$ & $0,13 \mathrm{~ns}$ & $0,83 * *$ \\
\hline PT & & & & & & & & & & 1 & $0,17 \mathrm{~ns}$ & $0,00 \mathrm{~ns}$ & $0,66^{* *}$ & $0,08 \mathrm{~ns}$ \\
\hline JBB & & & & & & & & & & & 1 & $0,34 \mathrm{~ns}$ & $0,13 \mathrm{~ns}$ & $0,11 \mathrm{~ns}$ \\
\hline JBIT & & & & & & & & & & & & 1 & $-0,44 \mathrm{~ns}$ & $0,73 * *$ \\
\hline B100 & & & & & & & & & & & & & 1 & $0,02 \mathrm{~ns}$ \\
\hline BBPP & & & & & & & & & & & & & & 1 \\
\hline
\end{tabular}

Keterangan: TT (Tinggi Tanaman), DB (Diameter Batang), JD (Jumlah Daun), LD (Lebar Daun), BBB (Bobot Brangkasan Segar), BBK (Bobot Brangkasan Kering), VA (Volume Akar), UP (Umur Panen), DT (Diameter Tongkol), PT (Panjang Tongkol), JBB (Jumlah Baris Biji), JBIT (Jumlah Biji/Tongkol), B100 (Bobot 100 Biji), BBPP (Bobot Biji/Petak).

Hubungan antara sifat pertumbuhan dengan komponen hasil berkisar antara sangat rendah hingga tinggi $(0,02<\mathrm{r}<0,66)$ dengan arah positif maupun negatif (Oktarina., 2016). Salami et al., (2007) menyatakan tinggi tanaman yang menunjukkan korelasi positif dengan hasil biji. Secara umum, komponen pertumbuhan dan hasil pada jagung memiliki hubungan antara cukup erat hingga sangat erat terhadap bobot biji/petak dengan arah yang positif. Hal ini menginformasikan bahwa semakin tinggi nilai komponen pertumbuhan dan hasil maka akan semakin meningkatkan hasil (Surtinah, 2018). Hasil penelitian Safitri et al. (2011) menunjukkan bahwa, pada tanaman padi, tinggi tanaman berkorelasi positif dan sangat nyata dengan panjang malai, jumlah gabah isi/malai, jumlah gabah total/malai, dan bobot 1000 butir gabah.

Komponen hasil secara umum berkorelasi positif sangat rendah hingga sangat tinggi terhadap hasil $(-0.01<\mathrm{r}<0.99)$. Korelasi yang sangat tinggi ditunjukkan oleh diameter tongkol $(\mathrm{r}=0,83)$ diikuti oleh jumlah biji/tongkol $(\mathrm{r}=0,73)$ (Tabel 2). Temuan serupa juga diungkapkan oleh Inamullah et al. (2011) bahwa hasil berkorelasi erat dengan panjang tongkol dan jumlah biji/tongkol. Hal ini menjelaskan bahwa hasil yang tinggi diperoleh ketika komponen hasil juga menunjukkan penampilan yang baik.

Dalam memilih genotip hasil tertinggi, studi korelasi memberikan informasi yang dapat dipercaya tentang sifat, luas dan arah seleksi. Pengetahuan tentang korelasi antara atribut hasil dan komponen komponenya yang berbeda membantu untuk mengetahui sifat dan besarnya hubungan antara sifat-sifat yang digunakan untuk mendapatkan hasil panen yang lebih baik.

Analisis korelasi dapat digunakan untuk mengetahui pola hubungan sifat antara produksi dengan karakter kuantitatif lainnya, namun menurut Safuan et al., (2014) dengan hanya menggunakan analisis korelasi tidak cukup untuk menggambarkan hubungan tersebut. Hal ini dikarenakan antar komponen-komponen hasil saling berkorelasi dan berpengaruh tidak langsung melalui komponen hasil dapat lebih berperan dari pada pengaruh langsung, masalah tersebut dapat diatasi dengan analisis lintasan (sidik lintas) karena masing-masing karakter yang dikorelasikan dengan hasil dapat diurai menjadi pengaruh langsung dan tidak langsung, sehingga hubungan kausal diantara karakter yang dikorelasikan dapat diketahui. Kontribusi koefisien lintas terhadap nilai korelasi beberapa karakter komponen hasil jagung dapat dilihat pada Tabel 3.

Sidik lintas telah banyak digunakan dalam pemuliaan tanaman untuk menentukan sifat hubungan antara hasil jagung dan komponen-komponennya, dan untuk mengidentifikasi komponen-komponen yang berpengaruh nyata terhadap hasil untuk potensi penggunaan sebagai kriteria seleksi (Puri et al., 1982; Mohammedein et al., 2017). Penentuan karakter yang digunakan untuk kriteria seleksi berdasarkan pada pedoman analisis lintas.Pedoman ini menyatakan bahwa korelasi merupakan korelasi sebenarnya dan pemilihan langsung oleh variabel dianggap efektif bila korelasi antar variabel serupa dengan efek langsungnya. 
Tabel 3. Pengaruh Langsung dan Tidak Langsung Antar Sifat Tanaman Jagung

\begin{tabular}{|c|c|c|c|c|c|c|c|c|c|c|c|c|c|c|}
\hline & \multicolumn{13}{|c|}{ PENGARUH LANGSUNG DAN PENGARUH TAK LANGSUNG } & \multirow{2}{*}{$\begin{array}{c}\begin{array}{c}\text { KO- } \\
\text { RELASI }\end{array} \\
\mathrm{Y} \\
\end{array}$} \\
\hline & TT & DB & JD & LUAD & BBB & BBK & VA & UP & DT & PT & JBB & JBIT & B100 & \\
\hline TT & $\underline{0.001}$ & 0.012 & 0.001 & 0.005 & -0.318 & 0.490 & 0.093 & -0.039 & 0.156 & -0.005 & 0.043 & 0.200 & 0.013 & 0.652 \\
\hline DB & 0.000 & $\underline{-0.024}$ & 0.000 & -0.009 & 0.171 & -0.267 & -0.038 & 0.074 & -0.099 & 0.009 & 0.078 & -0.254 & -0.015 & -0.375 \\
\hline JD & 0.000 & 0.005 & $\underline{0.002}$ & 0.003 & -0.090 & 0.127 & -0.060 & -0.097 & -0.006 & -0.005 & 0.146 & -0.061 & 0.003 & -0.033 \\
\hline LUAD & 0.000 & 0.017 & 0.001 & $\underline{0.013}$ & -0.125 & 0.031 & 0.037 & -0.018 & 0.069 & -0.002 & -0.082 & 0.170 & 0.035 & 0.144 \\
\hline BBB & 0.000 & 0.009 & 0.000 & 0.004 & $\underline{-0.449}$ & 0.681 & 0.060 & -0.119 & 0.222 & -0.013 & 0.036 & 0.298 & 0.031 & 0.761 \\
\hline BBK & 0.000 & 0.009 & 0.000 & 0.001 & -0.447 & $\underline{0.684}$ & 0.066 & -0.108 & 0.216 & -0.013 & 0.035 & 0.293 & 0.033 & 0.769 \\
\hline VA & 0.000 & 0.004 & -0.001 & 0.002 & -0.107 & 0.180 & $\underline{0.252}$ & 0.054 & 0.070 & 0.000 & -0.042 & -0.097 & 0.047 & 0.361 \\
\hline UP & 0.000 & -0.007 & -0.001 & -0.001 & 0.221 & -0.305 & 0.056 & $\underline{0.241}$ & -0.119 & 0.014 & -0.036 & -0.263 & 0.010 & -0.190 \\
\hline DT & 0.000 & 0.008 & 0.000 & 0.003 & -0.347 & 0.514 & 0.061 & -0.100 & $\underline{0.288}$ & -0.010 & -0.066 & 0.464 & 0.013 & 0.829 \\
\hline PT & 0.000 & 0.000 & 0.007 & 0.001 & -0.219 & 0.316 & 0.000 & -0.124 & 0.102 & $\underline{-0.028}$ & -0.043 & -0.001 & 0.065 & 0.078 \\
\hline JBB & 0.000 & 0.007 & -0.001 & 0.004 & 0.064 & -0.093 & 0.041 & 0.034 & 0.074 & -0.005 & $\underline{-0.257}$ & 0.229 & 0.013 & 0.110 \\
\hline JBIT & 0.000 & 0.009 & 0.000 & 0.003 & -0.197 & 0.295 & -0.036 & -0.094 & 0.197 & 0.000 & -0.087 & $\underline{0.678}$ & -0.043 & 0.726 \\
\hline B100 & 0.000 & 0.004 & 0.000 & 0.005 & -0.141 & 0.224 & 0.119 & 0.023 & 0.038 & -0.018 & -0.033 & -0.296 & $\underline{0.099}$ & 0.023 \\
\hline
\end{tabular}

Keterangan: TT (tinggi tanaman), DB (diameter batang), JD (jumlah daun), LD (lebar daun), UP (umur panen), DT (diameter tongkol), PT (panjang tongkol), JBB ( jumlah baris biji), JBIT (jumlah biji/tongkol), B100 (bobot kering 100 biji), BBB (bobot brangkasan segar), BBK (bobot brangkasan kering), VA (volume akar).

Bobot berangkasan kering menjadi variabel yang berpengaruh langsung dengan nilai yang tertinggi terhadap bobot biji/petak (0.684), diikuti dengan jumlah biji/tongkol (0.678) dengan nilai yang positif (Tabel 3). Diameter tongkol (0.288), volume akar (0.252), dan umur panen (0.241) memiliki pengaruh langsung bernilai positif yang rendah terhadap bobot biji/petak.Bobot 100 biji (0.099), luas daun (0.013), jumlah daun (0.002) dan tinggi tanaman (0.001) berpengaruh langsung yang terendah terhadap bobot biji/ petak. Komponen variabel lainnya yang meliputi bobot berangkasan segar (-0.449), jumlah baris biji (0.257), panjang tongkol (-0.028) dan diameter batang (-0.024) memiliki pengaruh langsung yang bernilai negatif. Hal ini didukung oleh Dewanti et al, (2015) yang menyatakan karakter jumlah biji/tongkol dan bobot 100 butir memiliki nilai pengaruh langsung dan pengaruh total yang besar dan positif.

Bobot berangkasan kering, jumlah biji/tongkol memiliki pengaruh langsung yang tinggi terhadap bobot biji/petak.Hal ini sesuai dengan nilai korelasi bahwa bobot berangkasan kering dan jumlah biji/ tongkol memiliki hubungan yang cukup hingga sangat tinggi terhadap bobot biji/petak.

Bobot berangkasan kering memiliki korelasi yang tinggi terhadap bobot biji/petak (Tabel 2). Korelasi tersebut terlihat pada pengaruh langsung bobot berangkasan kering terhadap bobot biji/petak yang tinggi. Selain itu, pengaruh tidak langsung bobot berangkasan kering terhadap bobot biji/petak tinggi melalui bobot berangkasan segar (0.447), diameter tongkol (0.216) dan jumlah biji/tongkol (0.293) arah positif.Oleh karena itu bobot berangkasan kering perlu ditingkatkan untuk mendapatkan hasil yang tinggi dalam budidaya jagung.
Hampir pada semua variabel memiliki pengaruh tidak langsung yang tinggi terhadap bobot biji/petak melalui bobot berangkasan kering. Variabel-variabel yang memiliki pengaruh tidak langsung tersebut adalah bobot berangkasan segar (0.681), diameter tongkol (0.514), tinggi tanaman $(0.490)$, panjang tongkol (0.316), umur panen (0.305), jumlah biji/ tongkol (0.295), diameter batang (0.267), dan bobot 100 biji (0.224) dengan arah yang positif. Variabel bobot berangkasan segar, diameter tongkol, tinggi tanaman, panjang tongkol, umur panen, diameter batang, dan bobot 100 biji memiliki pengaruh tidak langsung yang tinggi terhadap bobot biji/petak melalui bobot berangkasan kering meski pengaruh langsung dari variabel-variabel tersebut terhadap bobot biji/petak rendah. Hal ini menjelaskan bahwa bobot berangkasan kering memberikan pengaruh yang besar terhadap pertumbuhan dan perkembangan tanaman jagung.

Nilai residu merupakan nilai pengaruh langsung sisa yang belum terhitung pada karakter yang belum diidentifikasi (Kartina et al., 2017). Nilai residu mendekati nol (0.239) artinya sidik lintas yang digunakan sangat efektif menjelaskan sebab akibat dari nilai korelasi dan karakter yang diamati lengkap menjelaskan nilai-nilai pengaruh langsung maupun pengaruh tak langsungnya (Rohaeni et al., 2012).

Secara keseluruhan pada variabel bobot berangkasan kering dan jumlah biji/ tongkol memiliki pengaruh langsung yang tinggi terhadap bobot biji/ petak.Selain pengaruh langsung dari kedua variabel tersebut, apabila terdapat pengaruh tidak langsung yang tinggi maka perlu diperhatikan.Pengaruh tidak langsung yang cukup tinggi biasanya memiliki nilai korelasi yang cukup tinggi pula.Namun, hal tersebut 
tidak ditemukan pada penelitian ini. Meski nilai korelasi tinggi, namun pengaruh langsung dan tidak langsungnya rendah. Dengan demikian tidak dapat dilakukan penarikan kriteria pengaruh tidak langsung terhadap hasil.

\section{KESIMPULAN}

Berdasarkan hasil analisis korelasi, hasil hibrida jagung berhubungan erat dengan faktor pertumbuhannya sehingga hibrida jagung yang berproduksi tinggi didukung oleh diameter tongkol, bobot brangkasan segar, bobot brangkasan kering, tinggi tanaman, jumlah biji/tongkol yang pertumbuhannya bagus. Bobot berangkasan kering memiliki pengaruh langsung tertinggi terhadap bobot biji/petak, diikuti dengan jumlah biji/tongkol dengan nilai nilai korelasi positif. Peningkatan hasil jagung hibrida dapat diperoleh melalui peningkatan total biomasa tanaman dan peningkatan jumlah biji/ tongkol.

\section{DAFTAR PUSTAKA}

Badan Pusat Statistik. (2018). Produksi Jagung. Statistik Pertanian.Indonesia. http://bps.go.id. 11 Juli 2019.

Balai Besar Pengkajian dan Pengembangan Teknologi Pertanian. (2009). Data Pemeriksaan Curah Hujan. Bengkulu.

Dewanti, D., Basunada, P. \& A. Purwantoro, A.. (2015). Variabilitas karakter fenotipe dua populasi jagung manis (Zea mays L. Saccharata).Vegetalika, $4(4), 35-47$.

Gasperz, V. (1995). Teknik Analisis dalam Penelitian Percobaan. Tarsito, Bandung.

Haydar, A. Mandal, Ahmed, M.A., Hanan, M.B., Karim, M.M., Razvy, R., Roy, M.A., \& Salahin, M. (2007). Studies on genetic variability and interrelationship among the different traits in tomato (Lycopersicon esculentum Mill). MiddleEast Journal of Scientific Research, 2(3-4), 139-142.

Herawati, Efendi, R. \& Azrai, M. (2018). Indeks toleran dan karakter seleksi jagung inbrida toleran pemupukan nitrogen rendah. Bulletin Penelitian Tanaman Serealia, 2(3), 173-180. DOI: http://dx.doi.org/10.21082/jpptp.v2n3. 2018.p173-180.

Inamullah., Rehman, N., Shah, N.H., Arif, M. \& Siddiq, M. (2011). Correlations among grain yield and yield attributes in maize hybrids at various nitrogen levels. Sarhad Journal Agric, 27(4), 532-538.

Kartina, N. Wibowo, Widyastuti, B.P., Rumanti, Y. \& Satoto, I.A. (2017). Korelasi dan sidik lintas karakter agronomi padi hibrida. Penelitian Pertanian Tanaman Pangan, 1(1), 11-20. DOI: https://doi.org/10.18343/jipi.21.2.76.
Mustofa, Z., I. Budiarsa, M. \& Samdas, G.B.N. (2013). Variasi Genetik Jagung (Zea mays L) berdasarkan karakter fenotipik tongkol jagung yang dibudidyakan di Desa Jono Oge. Jurnal Ilmu Pengetahuan Biologi, 1, 33-41.

Mohammedein, B., Alhussein, A. \&.Idris, E. (2017). Correlation and Path Analysis of grain yield components in some maize (Zea mays L.) genotypes. Sudan. International Journal of Advanced Research and Publications (IJARP), 1 (1),79-82.

Oktarina, N. 2016. Korelasi Genetik Pertumbuhan dan Hasil 15 Jagung Hibrida. Skripsi. Fakultas Pertanian Universitas Bengkulu, Bengkulu.

Priyanto, S.B. Azrai, M. \& Makkulana, A.T. (2016). Parameter genetik dan korelasi karakter komponen hasil jagung hibrida. Buletin Penelitian Tanaman Serealia, 1(2), 9-15.

Puri Y. P, Qualset, C.O. \& Williams, W. A. (1982). Evaluation of yield components as selection criteria in barley breeding. Crop Sci., 22, 927-931.

Rahni, N.M. (2012). Karakteristik pertumbuhan dan hasil jagung pada ultisol yang diberi pupuk hayati dan pupuk hijau. Agriplus. 22(3), 162169.

Reddy, R. V. \& Jabeen, K. (2016). Narrow Sense Heratability, Correlation and Path Analysis in Maize (Zea mays L.). Sabrao Journal of Breeding and Genetic. 48(2), 120-126.

Riwandi., Handajaningsih,M. \& Hasanudin. (2014). Teknik Budidaya Jagung dengan Sistem Organik di Lahan Marjinal. UNIB Press., Bengkulu.

Safitri, H. Purwoko, B.S. Dewi, I.S \& Abdullah, B. (2011). Korelasi dan sidik lintas karakter fenotipik galur-galur padi haploid ganda hasil kultur Antera. Widyariset, 14(2), 295304.

Safuan, L.O. Boer, D. Wijayanto, T. \& Susanti, N. (2014). Analisis koefisien lintas berbagai sifat agronomis yang mempengaruhi hasil kultivar jagung pulut (Zea mays Ceritina Kulesh) Lokal Sulawesi Tenggara. Kendari. Agriplus. 24(2), 136-143.

Salami, A. E., Adegoke, S. A. O. \& Adegbite, O.A. (2007). Genetic variability among maize cultivars grown in Ekiti-State, Nigeria. Middle-East J. Sci. Res, 2(1), 09-13.

Sarwono, J. (2009). Statistik itu Mudah: Panduan Lengkap Untuk Belajar Komputerisasi Statistik Menggunakan SPSS 2016. Andi Publisher, Yogyakarta.

Singh, R. K. \& Chaudhary, B. D. (1979). Biometrical Methods in Quantitative Genetics Analysis. Kalyani Publishers, New Delhi. 
PENNITA et al.

Surtinah. 2018. Korelasi fenotype dan hasil jagung manis (Zea mays Saccharata, Sturt) di Kecamatan Rumbai Pekan Baru. Jurnal Ilmiah Pertanian, 15(1), 7-12. DOI: https://doi.org/ 10.31849/jip.v15i1.1478
Taufik, M., Suprapto \& Widiyono, H. (2010). Uji daya hasil pendahuluan jagung hibrida di lahan ultisol dengan input rendah. Akta Agrosia, 13(1), 70-76. 